\title{
Physical behaviour of dairy ingredients during ice cream processing
}

\author{
Punsandani UdABAGE*, Mary Ann AUgustin, Li Jiang CHENG, \\ Roderick P.W. WILLIAMS
}

Food Science Australia, Private Bag 16, Sneydes Road, Werribee, Victoria 3030, Australia

Published online 5 July 2005

\begin{abstract}
The characteristics of aged ice cream mixes $\left(110 \mathrm{~g} \cdot \mathrm{kg}^{-1}\right.$ milkfat, $110 \mathrm{~g} \cdot \mathrm{kg}^{-1}$ non-fat milk solids, $140 \mathrm{~g} \cdot \mathrm{kg}^{-1}$ sugar, $2 \mathrm{~g} \cdot \mathrm{kg}^{-1}$ stabilizers and $2 \mathrm{~g} \cdot \mathrm{kg}^{-1}$ emulsifier) and the final ice cream prepared with various milk solids non-fat were examined. The milk solids non-fat powders used were low heat skim milk powder (LHSMP), whey protein concentrate with $350 \mathrm{~g} \cdot \mathrm{kg}^{-1}$ crude protein (WPC 35 ), and unheated and heated blends (1:1 ratio) of LHSMP and WPC 35. The source of the milk solids non-fat and the heat treatment applied during powder manufacture influenced the characteristics of the ice cream mix and the properties of the final ice cream. The results suggest that alteration of the emulsion characteristics of ice cream mixes with the use of milk solids non-fat with different proportions of caseins to whey proteins and increased whey protein denaturation altered the ice cream properties. The use of a high heat-treated blend of LHSMP and WPC 35 resulted in ice creams with the best melt resistance.
\end{abstract}

ice cream / whey protein / heat treatment / melt resistance

Résumé - Comportement physique des ingrédients laitiers durant la fabrication de la crème glacée. On a étudié les caractéristiques des mélanges pour crème glacée maturés $\left(110 \mathrm{~g} \cdot \mathrm{kg}^{-1} \mathrm{de}\right.$ matière grasse de lait, $110 \mathrm{~g} \cdot \mathrm{kg}^{-1} \mathrm{~d}$ 'extrait sec dégraissé, $140 \mathrm{~g} \cdot \mathrm{kg}^{-1}$ de sucre, $2 \mathrm{~g} \cdot \mathrm{kg}^{-1} \mathrm{de}$ stabilisants et $2 \mathrm{~g} \cdot \mathrm{kg}^{-1}$ d'émulsifiants) et de la crème glacée résultante, préparée avec (i) des poudres de lait écrémé traitées à basse température (LHSMP), (ii) des concentrés de protéines de lactosérum avec une teneur en protéine brute de $350 \mathrm{~g} \cdot \mathrm{kg}^{-1}$ (WPC 35) et (iii) des mélanges chauffés ou non (taux 1:1) de LHSMP et WPC 35. Le type d'ingrédient utilisé et le traitement thermique appliqué durant la fabrication de la poudre influençaient les caractéristiques des mélanges pour crème glacée et les propriétés de la crème glacée finale. L'altération des caractéristiques d'émulsion des mélanges pour crème glacée avec l'emploi de poudres ayant différentes proportions de caséines par rapport aux protéines du lactosérum et la dénaturation accrue des protéines du lactosérum modifiaient les propriétés de la crème glacée. L'utilisation de mélange traité à haute température de LHSMP et WPC 35 permettait l'obtention de crèmes glacées qui offraient une meilleure résistance à la fusion.

crème glacée / protéine du lactosérum / traitement thermique / résistance à la fusion

\footnotetext{
* Corresponding author: punsandani.udabage@ csiro.au
} 


\section{INTRODUCTION}

Dairy ice cream is a complex matrix consisting of ice, air, fat and the concentrated unfrozen serum. The approximate phase volumes are $\sim 250 \mathrm{~mL} \cdot \mathrm{L}^{-1}$ for ice, $\sim 500 \mathrm{~mL} \cdot \mathrm{L}^{-1}$ for air, $50 \mathrm{~mL} \cdot \mathrm{L}^{-1}$ for fat and $\sim 200 \mathrm{~mL} \cdot \mathrm{L}^{-1}$ for serum [2]. The ice cream properties are determined by its formulation and the processing conditions used in its manufacture $[1,8,12,19]$.

A typical regular ice cream formulation consist of $350-370 \mathrm{~g} \cdot \mathrm{kg}^{-1}$ total solids (TS) with $100-120 \mathrm{~g} \cdot \mathrm{kg}^{-1}$ fat, $100-110 \mathrm{~g} \cdot \mathrm{kg}^{-1}$ milk solids non-fat (MSNF), $130-160 \mathrm{~g} \cdot \mathrm{kg}^{-1}$ sweetener and $2-4 \mathrm{~g} \cdot \mathrm{kg}^{-1}$ stabilisers and emulsifiers [19]. The source of milk solids used in an ice cream formulation, as well as the conditions used in the preparation of the milk ingredient, both influence the ice creams' properties $[9,16,28]$. Improved melt resistance of ice cream was obtained when lower temperatures for longer times were used for pasteurisation $[17,18]$. Pre-processing of whey proteins to form microparticulated whey proteins is reported to stabilise an ice cream foam and increase its resistance to meltdown [14].

The major steps in the manufacture of ice cream include preparation of the ice cream mix, homogenisation, pasteurisation, cooling, ageing, freezing and churning. The formulation and stability of the ice cream emulsion is an integral part of ice cream manufacture and has a significant effect on the properties of the final ice cream. The stability of emulsions is influenced by the surface coverage of the fat globule, the dimensions of the adsorbed layer and the surface viscosity [6]. The ability of a protein to form and stabilise an emulsion is dependent on its ability to adsorb, rapidly unfold and spread at the droplet interface.

During emulsification of the ingredients (i.e. before heating), caseins are preferentially transferred to the oil - water interface in comparison to whey proteins, dominating the adsorbed layer thickness and producing a stabilising layer [5, 29]. Upon heating, the whey proteins competitively displace the caseins from the interface except $\kappa$-casein which resists displacement due to complex formation with $\beta$-lactoglobulin [5].

Churning of the ice cream mix prior to hardening sets up the ice cream structure as it results in fat destabilisation and the partial coalescence of globules that leads to the formation of a fat network $[13,23]$. The agglomerated fat network is capable of stabilising the foam lamellae and reducing drainage which leads to increased melt resistance in ice cream [15].

Some of the common dairy ingredients used in ice cream include skim milk concentrate, fresh cream, butter, anhydrous milk fat (AMF), skim milk powder (SMP), buttermilk powder and whey powders or concentrates. SMP and whey protein concentrate with $35 \%$ crude protein (WPC 35) are common ingredients in the market place. Traditionally, SMP has been sold as low heat, medium heat or high heat powders. WPC 35 powders have generally been exposed to pasteurisation conditions during their manufacture. While blends of milk powder and WPC 35 have been used in a variety of formulations, there is still a lack of understanding about the relative effects of unheated blends and high heat-treated blends of these ingredients on ice cream properties. This work compared the characteristics of ice cream mix emulsions made with low heat skim milk powder (LHSMP), WPC 35, an unheated and a high heattreated blend (1:1 ratio) of LHSMP and WPC 35 and their relationship to the properties of the final ice cream.

Ice cream is a complex system with many ingredients in its formulation that can interact. The formulation as well as the actual processing conditions used in its manufacture can affect the final properties of the ice cream. In this paper, the aim was to compare if the properties of ice cream were altered by changing the milk protein and the heat treatment given to the protein prior to the formulation of the ice cream mix whilst the emulsifiers and stabilisers were kept 
constant. However, it should be borne in mind that there can be interactions between the emulsifiers, stabilisers and different milk proteins, which will be dependent both on the type and state of the protein used in the formulation, which can also affect the properties of ice cream mixes and ice cream.

\section{MATERIALS AND METHODS}

\subsection{Materials}

LHSMP was manufactured in May 2001 at the pilot plant of Food Science Australia, Melbourne Laboratory. LHSMP was prepared by pasteurising milk at $72{ }^{\circ} \mathrm{C}$ for $30 \mathrm{~s}$ prior to concentration to $\sim 440 \mathrm{~g} \cdot \mathrm{kg}^{-1} \mathrm{TS}$ in a falling film evaporator and drying to $\sim 40 \mathrm{~g} \cdot \mathrm{kg}^{-1}$ moisture in a Niro production Minor spray drier (Niro A/S, Soeborg, Denmark). WPC 35 and AMF were obtained from Murray Goulburn Co-Operative Ltd, Victoria, Australia. For the unheated blend, a 1: 1 mixture of LHSMP and WPC 35 powders was dry blended. For the preparation of the heated blend (1:1 LHSMP and WPC 35), a 1:1 blend of LHSMP and WPC 35 powders was reconstituted to obtain a $100 \mathrm{~g} \cdot \mathrm{kg}^{-1}$ TS suspension. The $\mathrm{pH}$ of this suspension was adjusted to 6.9 with $1 \mathrm{~mol} \cdot \mathrm{L}^{-1} \mathrm{NaOH}$ and the mixture was heated at $90{ }^{\circ} \mathrm{C}$ for $10 \mathrm{~min}$ prior to concentration and drying (Niro A/S).

The stabilizers guar gum, sodium carboxymethyl-cellulose (CMC) and the emulsifier mono-and di-glycerides of fat forming fatty acids (saturated fatty acid) were supplied by Germantown International Ltd., NSW, Australia. The sugar was bought from a local supermarket.

\subsection{Preparation of ice creams}

A dry blend of CMC, guar gum and sucrose was suspended in water at $40^{\circ} \mathrm{C}$ to obtain a $317 \mathrm{~g} \cdot \mathrm{kg}^{-1} \mathrm{TS}$ solution and stirred for $\sim 30 \mathrm{~min}$ at $40^{\circ} \mathrm{C}$ to dissolve and hydrate the ingredients. Milk powder was dispersed in water $\left(40{ }^{\circ} \mathrm{C}\right)$ to obtain a $250 \mathrm{~g} \cdot \mathrm{kg}^{-1}$ MSNF suspension and stirred for $\sim 30 \mathrm{~min}$ at $40^{\circ} \mathrm{C}$. The required amount of $3 \mathrm{~mol} \cdot \mathrm{L}^{-1}$ $\mathrm{NaOH}$ or $320 \mathrm{~g} \cdot \mathrm{kg}^{-1} \mathrm{HCl}$ was added to achieve a pH of 6.40 at $25^{\circ} \mathrm{C}$. The amount of $\mathrm{NaOH}$ and $\mathrm{HCl}$ used did not contribute significantly to the final weight of the suspension. AMF was melted at $\sim 60{ }^{\circ} \mathrm{C}$ and mixed with the emulsifier just before mixing it with the other ingredients. The appropriate amounts of the ingredients prepared were mixed at $40{ }^{\circ} \mathrm{C}$ and stirred for $\sim 30 \mathrm{~min}$ to obtain ice cream mix formulations consisting of $110 \mathrm{~g} \cdot \mathrm{kg}^{-1}$ milkfat, $110 \mathrm{~g} \cdot \mathrm{kg}^{-1}$ MSNF, $140 \mathrm{~g} \cdot \mathrm{kg}^{-1}$ sugar, $2 \mathrm{~g} \cdot \mathrm{kg}^{-1}$ stabilizer and $2 \mathrm{~g} \cdot \mathrm{kg}^{-1}$ emulsifier. The ice cream mixes were homogenised $(17.5+3.5 \mathrm{MPa})$, pasteurised at $80{ }^{\circ} \mathrm{C}$ for $25 \mathrm{~s}$, cooled to $\sim 4{ }^{\circ} \mathrm{C}$ and aged overnight $\left(4^{\circ} \mathrm{C}\right)$. On the next day, each of the aged mixes were frozen and whipped (churned) using a APV ice cream freezer (APV ice cream Europe, Aarhus, Højbjerg, Denmark) to obtain $\sim 70 \%$ overrun, collected in waxed containers and hardened at $-22{ }^{\circ} \mathrm{C}$. The characterization and the functional testing were carried out on aged ice cream mixes and ice creams hardened for $7 \mathrm{~d}$.

Duplicate manufacturing trials were carried out approximately two months apart using the same powders.

\subsection{Physical and functional properties}

\subsubsection{Analysis of powders and ice cream mixes}

The total fat contents of the powder and ice cream mixes were determined using the Mojonnier method [24] using $\mathrm{HCl}$ instead of ammonia. For the estimation of solvent extractable fat (SEF), $50 \mathrm{~mL}$ of petroleum ether (b.p. $40-60^{\circ} \mathrm{C}$ ) was added to $10 \mathrm{~g}$ of sample. The mixture was agitated in a stoppered flask for $15 \mathrm{~min}$. This was followed by filtration and evaporation of the solvent at $60{ }^{\circ} \mathrm{C}$. The fat was then dried in a $102{ }^{\circ} \mathrm{C}$ oven to constant weight. SEF is expressed 
as grams of solvent extractable fat in $1 \mathrm{~kg}$ of sample.

The $\mathrm{pH}$ of the ice cream mixes (before ageing) was tested at $25^{\circ} \mathrm{C}$ using a combined $\mathrm{pH}$ glass electrode (Radiometer A/S., Copenhagen NV, Denmark).

The total nitrogen of the milk powders and the ice cream mixes, the true protein nitrogen and the casein nitrogen of the milk powders were determined in a Leco FP 2000 nitrogen analyser (LECO Corporation, Michigan, USA) according to the method described in the Provisional IDF standard [11].

True protein nitrogen: A modification of AOAC method 991.22 [25] was used for the determination of true protein nitrogen. The milk powders were reconstituted in water $(10 \%)$ and the protein precipitated with $120 \mathrm{~g} \cdot \mathrm{kg}^{-1}$ trichloroacetic acid (TCA). The samples were mixed using a vortex mixer and allowed to stand for $10 \mathrm{~min}$. The precipitated protein was next pelleted by centrifugation (Sigma $201 \mathrm{M}$ centrifuge) at room temperature (14000 rpm / $10 \mathrm{~min})$. The supernatant was decanted and the pellet washed with $150 \mathrm{~g} \cdot \mathrm{kg}^{-1}$ TCA and collected again by centrifugation. The pellets were then resuspended in $1 \mathrm{~mol} \cdot \mathrm{L}^{-1} \mathrm{NaOH}$ and dried in a Leco sample crucible.

Casein nitrogen: A modification of AOAC method 998.06 [26] was used for the determination of casein nitrogen. The milk powders were reconstituted in water $\left(100 \mathrm{~g} \cdot \mathrm{kg}^{-1}\right)$ and the protein precipitated at $\mathrm{pH} 4.6$ using a acetic acid/sodium acetate buffer. The samples were mixed using a vortex mixer and allowed to stand for $10 \mathrm{~min}$. The precipitated protein was pelleted by centrifugation (Sigma $201 \mathrm{M}$ centrifuge) at room temperature (14000 rpm / $10 \mathrm{~min})$. The supernatant was decanted and the pellet washed with the acetate buffer and collected again by centrifugation. The pellets were then resuspended in $\mathrm{NaOH}\left(1 \mathrm{~mol} \cdot \mathrm{L}^{-1}\right)$ and dried in a Leco sample crucible.

The factor 6.38 was used to convert nitrogen to protein concentration [10].

\subsubsection{Particle size distribution}

Particle size distributions (PSD) of ice cream mixes and thawed ice creams were determined at room temperature using a Malvern Mastersizer 2000 (Malvern Instruments Ltd, Malvern, UK). The samples were dispersed in distilled water to obtain an obscuration of between $10-30 \%$. A refractive index of 1.456 [20] and an absorption coefficient of 0.01 was assumed for all samples with AMF.

\subsubsection{Viscosity measurements}

The viscosities of the aged ice cream mixes were monitored at $4{ }^{\circ} \mathrm{C}$ as a function of shear rate $\left(0.29-231 \mathrm{~s}^{-1}\right)$ with a Bohlin VOR Rheometer (Bohlin Rheologi AB, Sweden) using a concentric cylinder (C25) geometry. A small volume of the sample was placed in the cup and the bob was lowered to position and a slight excess of the sample was allowed to cover the top of the bob. Measurements were started 5 min after placing the sample in the cup, to allow for temperature equilibration.

\subsubsection{Overrun}

The mass of a fixed volume of aged ice cream mix was compared to the mass of the same volume of churned ice cream at intervals during the churning and aeration process. The \% overrun was calculated as below:

$$
\begin{aligned}
& \% \text { Overrun }= \\
& \frac{\text { Weight of aged ice cream mix }- \text { Weight of ice cream }}{\text { Weight of ice cream }} \\
& \quad \times 100
\end{aligned}
$$

\subsubsection{Melt down test}

Samples of ice cream $(500 \mathrm{~mL})$ stored at $-22{ }^{\circ} \mathrm{C}$ were removed from their waxed containers, weighed and placed on $\sim 30$ mesh wire screens at room temperature $\left(22 \pm 1{ }^{\circ} \mathrm{C}\right)$ and the weight of the melt (drainage) was recorded at $15 \mathrm{~min}$ intervals for $120 \mathrm{~min}$. 
Table I. The characterization of dairy powders used in ice cream production.

\begin{tabular}{lrrcc}
\hline & LHSMP & WPC 35 & $\begin{array}{c}\text { (1:1) Blend of } \\
\text { LHSMP and } \\
\text { WPC 35 Unheated }\end{array}$ & $\begin{array}{c}\text { (1:1) Blend of } \\
\text { LHSMP and } \\
\text { WPC 35 Heated }\end{array}$ \\
\hline Total Solids $\left(\mathrm{g} \cdot \mathrm{kg}^{-1}\right)$ & $961.1 \pm 0.4$ & $962.5 \pm 0.5$ & $961.3 \pm 0.3$ & $960.4 \pm 0.2$ \\
Total Fat $\left(\mathrm{g} \cdot \mathrm{kg}^{-1}\right)$ & $5.1 \pm 0.8$ & $38.0 \pm 1.3$ & $21.9 \pm 0.3$ & $21.2 \pm 0.7$ \\
Solvent Extractable Fat & $0.7 \pm 0.1$ & $1.8 \pm 0.1$ & $1.1 \pm 0.1$ & $0.9 \pm 0.1$ \\
(g SEF $\mathrm{kg}^{-1}$ total fat) & & & & $368.8 \pm 0.1$ \\
Crude Protein $\left(\mathrm{g} \cdot \mathrm{kg}^{-1}\right)$ & $401.1 \pm 0.9$ & $362.0 \pm 0.7$ & $375.5 \pm 9.8$ & $367.3 \pm 0.9$ \\
True Protein $\left(\mathrm{g} \cdot \mathrm{kg}^{-1}\right)$ & $394.1 \pm 1.3$ & $336.1 \pm 1.4$ & $367.9 \pm 0.3$ & $310.7 \pm 2.0$ \\
$\mathrm{pH}$ 4.6 Insoluble Protein $\left(\mathrm{g} \cdot \mathrm{kg}^{-1}\right)$ & $319.6 \pm 0.6$ & $32.6 \pm 0.3$ & $169.5 \pm 1.4$ & $56.6 \pm 2.9$ \\
$\mathrm{pH}$ 4.6 Soluble Protein $\left(\mathrm{g} \cdot \mathrm{kg}^{-1}\right)$ & $74.5 \pm 1.9$ & $303.5 \pm 1.7$ & $198.4 \pm 1.7$ & \\
\hline
\end{tabular}

Averages of triplicate measurements with SD, except for total fat and SEF where averages of duplicate measurements with the ranges are given.

\section{RESULTS AND DISCUSSION}

\subsection{Characteristics of powdered ingredients}

The characteristics of the powders used are given in Table I. The true protein content of the powders ranged from 336.1$394.1 \mathrm{~g} \cdot \mathrm{kg}^{-1}$. The higher amount of $\mathrm{pH} 4.6$ insoluble protein of the heated 1:1 blend of LHSMP and WPC 35 compared to the unheated mixture is expected due to the denaturation of the whey protein caused by the heat treatment.

\subsection{Properties of ice cream mixes}

The ice cream mixes had $\mathrm{pH}$ of $6.50 \pm$ 0.04 and fat contents of $111.1 \pm 3.2 \mathrm{~g} \cdot \mathrm{kg}^{-1}$ and crude protein contents of $42.9 \pm$ $3.3 \mathrm{~g} \cdot \mathrm{kg}^{-1}$, which is a typical composition of an ice cream [19].

\subsubsection{Solvent extractable fat}

The SEF contents of ice cream mixes were low $\left(<1.0 \mathrm{~g} \cdot \mathrm{kg}^{-1}\right)$. Changing the source of MSNF in the ice cream formulation did not have a marked effect on the SEF of the aged ice cream mixes (Tab. II), possibly due to the presence of sufficient sur- face active material (both proteins and added emulsifiers) for stabilization of the milkfat globules in the homogenised mix.

\subsubsection{Particle size distribution}

The PSD of aged ice cream mixes made with LHSMP and the unheated blend had a peak maximum around $1 \mu \mathrm{m}$. The PSD of aged ice cream mixes made with WPC 35 or the heated blend was bimodal with the first peak maximum around $0.25 \mu \mathrm{m}$ for both distributions and the second peak maxima around $3.5 \mu \mathrm{m}$ and $9 \mu \mathrm{m}$ for ice cream mix made with WPC 35 and heated blend, respectively (Tab. II, Fig. 1). The ice cream mixes with larger PSD had a lower cumulative percentage at $2.2 \mu \mathrm{m}$ as expected (Tab. II). The PSD results suggest that the ice cream mix was a more stable emulsion with the use of SMP compared to the use of WPC 35, which is in agreement with the observations of Gelin et al. [7] and Pelan et al. [21]. Gelin et al. [7] observed a monomodal distribution for ice cream mixes made with SMP and a bimodal distribution for ice cream mixes made with WPC 35. The shift to the larger particle size in mixes with WPC 35 can be attributed to pronounced flocculation of ice cream mixes 
Table II. The properties of aged ice cream mixes.

\begin{tabular}{|c|c|c|c|c|c|c|c|c|c|c|c|c|}
\hline \multirow[t]{2}{*}{ Parameter } & \multicolumn{3}{|c|}{ LHSMP } & \multicolumn{3}{|c|}{ WPC 35} & \multicolumn{3}{|c|}{$\begin{array}{c}\text { (1:1) Blend of } \\
\text { LHSMP and } \\
\text { WPC } 35 \text { Unheated }\end{array}$} & \multicolumn{3}{|c|}{$\begin{array}{c}\text { (1:1) Blend of } \\
\text { LHSMP and } \\
\text { WPC } 35 \text { Heated }\end{array}$} \\
\hline & $\begin{array}{c}\text { Trial } \\
(1)\end{array}$ & $\begin{array}{l}\text { Trial } \\
(2)\end{array}$ & $\begin{array}{l}\text { Pooled } \\
\text { SD }\end{array}$ & $\begin{array}{l}\text { Trial } \\
\text { (1) }\end{array}$ & $\begin{array}{l}\text { Trial } \\
\text { (2) }\end{array}$ & $\begin{array}{l}\text { Pooled } \\
\text { SD }\end{array}$ & $\begin{array}{c}\text { Trial } \\
\text { (1) }\end{array}$ & $\begin{array}{c}\text { Trial } \\
(2)\end{array}$ & $\begin{array}{l}\text { Pooled } \\
\text { SD }\end{array}$ & $\begin{array}{l}\text { Trial } \\
\text { (1) }\end{array}$ & $\begin{array}{l}\text { Trial } \\
(2)\end{array}$ & $\begin{array}{l}\text { Pooled } \\
\text { SD }\end{array}$ \\
\hline $\begin{array}{l}\text { Solvent Extractable Fat } \\
\text { (g SEF } \cdot \mathrm{kg}^{-1} \text { total fat) }\end{array}$ & 0.4 & 0.5 & 0.1 & 0.6 & 0.6 & 0.1 & 0.6 & 0.6 & 0.1 & 0.5 & 0.6 & 0.1 \\
\hline Particle Mode $(\mu \mathrm{m})$ & 1.085 & 0.944 & 0.003 & 3.403 & 3.241 & 0.014 & 1.193 & 1.150 & 0.007 & 9.218 & 8.606 & 0.146 \\
\hline $\begin{array}{l}\text { Particle cumulative } \% \\
\text { at } 2.2 \mu \mathrm{m}\end{array}$ & 96.48 & 98.98 & 0.09 & 32.76 & 637.82 & 0.52 & 85.50 & 87.78 & 0.43 & 8.49 & 11.74 & 0.41 \\
\hline
\end{tabular}

Average of at least duplicate analysis with pooled SD.

made with WPC 35 after homogenisation due to the reduced ability of WPC 35 to stabilize the emulsion and prevent flocculation. The work of Gelin et al. [7] and Pelan et al. [21] also showed that more proteins were adsorbed per unit surface area in emulsions made with SMP compared to emulsions made with WPC 35.

When the unheated blend (1:1 LHSMP and WPC 35) was used the PSD was similar to that of mixes containing LHSMP alone. This suggested that the caseins within the LHSMP and WPC 35 unheated blend had a dominant effect over that of the whey proteins. The results confirmed that native casein micelles stabilize the ice cream mix emulsion more effectively than WPC 35, a conclusion supported by the smaller particle size in the ice cream mix made with the unheated LHSMP and WPC 35 blend compared to that made with WPC 35 alone. However, when the heated blend of LHSMP and WPC 35 was used, a bimodal distribution, with features similar to that for mixes with WPC 35 alone, was obtained except that the size of the larger particles were much greater than those for mixes with WPC 35 alone. The application of heat during the preparation of the heated blend of LHSMP and WPC 35, caused heat denaturation of the whey proteins and binding of the denatured $\beta$-lactoglobulin $(\beta-\lg )$ to $\kappa$-casein [3, 4]. The increase in particle size (Fig. 1)

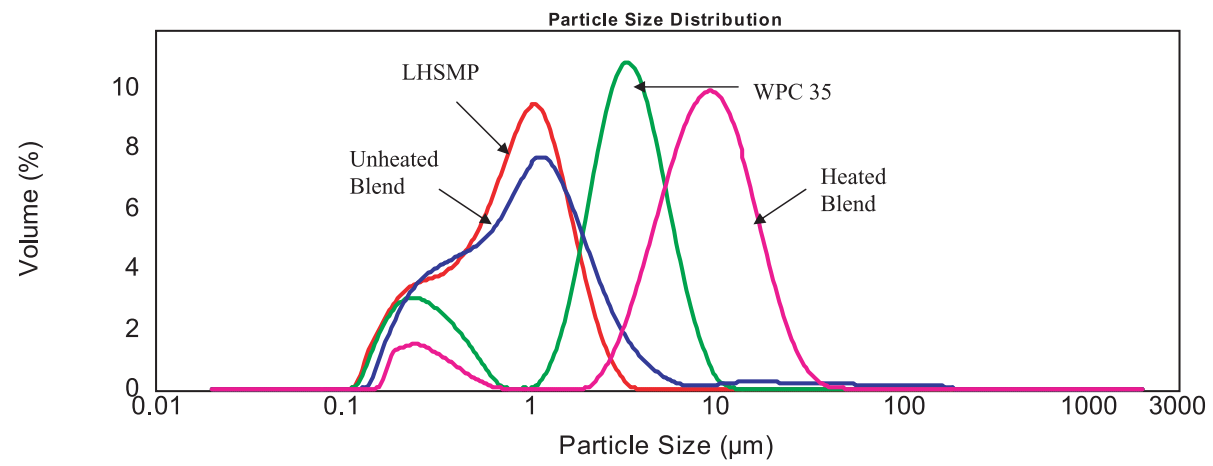

Figure 1. Effect of MSNF type on the particle size distribution of aged ice cream mixes (Results from trial 1; trial 2 trends were similar). 


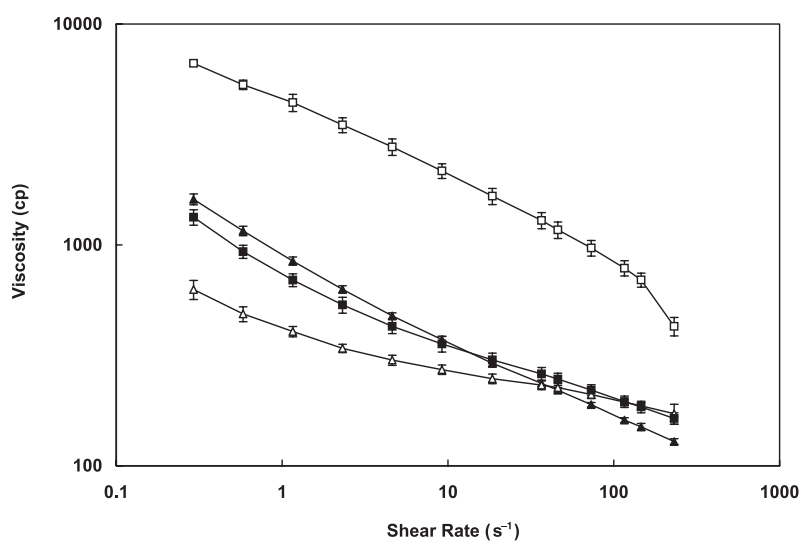

Figure 2. Effect of MSNF type on the viscosity $\left(\right.$ at $\left.4{ }^{\circ} \mathrm{C}\right)$ of aged ice cream mixes made with $-\Delta-$ LHSMP, $-\triangle-$ WPC 35 , - - Unheated blend and $-\square-$ Heated blend (Average of duplicate measurements from trial 1 with pooled SD, trial 2 trends were similar). observed in the ice cream mix made with the heated blend of LHSMP and WPC 35 compared to that made with the unheated blend could be due to the reduced ability of the denatured whey proteins in its aggregated state to effectively stabilize the emulsion and the reduction in the available protein to be adsorbed at the droplet interface, thereby promoting flocculation and possible network formation.

\subsubsection{Viscosity of ice cream mixes}

The ice cream mix made with the heated blend had the highest viscosity at all shear rates. The viscosity of the WPC 35 ice cream mix was the lowest below a shear rate of $\sim 10 \mathrm{~s}^{-1}$ but at higher shear rates the viscosity of this mix was not markedly different to the viscosities of ice cream mixes made with LHSMP or the unheated blend of LHSMP and WPC 35. (Fig. 2). Lee and White [16] observed a general decrease in the viscosity at $12 \mathrm{rpm}$ (using a Brookfield Viscometer with a T-bar spindle) with increasing levels of WPC 36 in the solids non-fat (SNF) component of the ice cream formulation. In that study the $\mathrm{pH}$ of the mixes was not standardised and a decrease in $\mathrm{pH}$ was observed with the increase in the substitution of the WPC 36. However, Goff et al. [9] observed an increase in the viscosity measured at $30 \mathrm{rpm}\left(6.6 \mathrm{~s}^{-1}\right)$ using a
Brookfield Viscometer with spindle 1, with the substitution of more than half the nonfat dry milk (NDM) with WPC 36. The differences obtained in various studies could be due to the different conditions used for both the preparation of the mixes and the measurements as the viscosity of these mixes is shear-dependent. The increase in the viscosity of the ice cream mix made with the heated blend could be due to the larger size of the particles in these emulsions (Tab.II, Fig. 1) and the formation of a weak gel-like structure in these ice cream mixes due to the presence of heat denatured aggregates of whey proteins and denatured whey - casein complexes.

Thermodynamic incompatibility of biopolymers leads to phase separation resulting in localised concentrations of protein and stabilisers [22, 27], which could alter the viscosity of the ice cream mix. Furthermore, the same phenomena is capable of contributing to the structure development and functionality of the hardened ice cream, by localizing high concentrations of milk protein at the ice crystal interface and exerting a water holding action, that markedly enhances the stabiliser effect [22].

\subsubsection{Aeration properties}

The aeration properties of the ice cream mixes were affected by the source of MSNF 
Table III. Properties of ice cream hardened for 7 days.

\begin{tabular}{|c|c|c|c|c|c|c|c|c|c|c|c|c|}
\hline \multirow[t]{2}{*}{ Parameter } & \multicolumn{4}{|c|}{ LHSMP } & \multicolumn{2}{|c|}{ WPC 35} & \multicolumn{3}{|c|}{$\begin{array}{c}(1: 1) \text { Blend of } \\
\text { LHSMP and } \\
\text { WPC } 35 \text { Unheated }\end{array}$} & \multicolumn{3}{|c|}{$\begin{array}{c}\text { (1:1) Blend of } \\
\text { LHSMP and } \\
\text { WPC } 35 \text { Heated }\end{array}$} \\
\hline & $\begin{array}{c}\text { Trial } \\
(1)\end{array}$ & $\begin{array}{l}\text { Trial } \\
(2)\end{array}$ & $\begin{array}{l}\text { Pooled } \\
\text { SD }\end{array}$ & $\begin{array}{l}\text { Trial } \\
(1)\end{array}$ & $\begin{array}{l}\text { Trial } \\
(2)\end{array}$ & $\begin{array}{l}\text { Pooled } \\
\text { SD }\end{array}$ & $\begin{array}{c}\text { Trial } \\
(1)\end{array}$ & $\begin{array}{l}\text { Trial } \\
(2)\end{array}$ & $\begin{array}{l}\text { Pooled } \\
\text { SD }\end{array}$ & $\begin{array}{l}\text { Trial } \\
(1)\end{array}$ & $\begin{array}{l}\text { Trial } \\
(2)\end{array}$ & $\begin{array}{l}\text { Pooled } \\
\text { SD }\end{array}$ \\
\hline Overrun $(\%)^{*}$ & $73 \pm 2$ & $70 \pm 3$ & N/A & 69 & $77 \pm 4$ & N/A & $75 \pm 2$ & $70 \pm 2$ & N/A & $75 \pm 1$ & $72 \pm 3$ & N/A \\
\hline $\begin{array}{l}\text { SEF } \\
\left(\mathrm{g} \mathrm{SEF} \cdot \mathrm{kg}^{-1} \text { total fat }\right)\end{array}$ & 2.1 & 1.6 & 0.2 & 0.8 & 1.1 & 0.1 & 0.7 & 1.9 & 0.1 & 2.2 & 9.3 & 0.04 \\
\hline Particle Mode $(\mu \mathrm{m})$ & 1.022 & 0.887 & 0.007 & 0.447 & 0.675 & 0.033 & 0.907 & 0.963 & 0.009 & 1.165 & 1.141 & 0.027 \\
\hline $\begin{array}{l}\text { Particle cumulative } \\
\% \text { at } 2.2 \mu \mathrm{m}\end{array}$ & 84.99 & 89.88 & 0.75 & 97.12 & 94.45 & 0.35 & 94.34 & 89.37 & 0.42 & 74.08 & 70.88 & 1.92 \\
\hline
\end{tabular}

Average of at least duplicate analysis with pooled SD.

* Overrun averages with SD $(n>4)$.

used. The ease of aeration (observed) increased in the following order: ice cream mixes with WPC $35>$ LHSMP $\sim$ unheated blend (1:1 LHSMP and WPC 35) $>$ heated blend (1:1 LHSMP and WPC 35). Aeration is affected by the coalescence tendency of the fat globules under the combined influence of agitation and freezing and the ability of the aerated mix to stabilise air cells. The fat globule membrane in mixes with whey protein alone is thin and not as robust as when the mix contains caseins making the former mixes more prone to damage during agitation and freezing and hence easier to aerate. The lower viscosity of the WPC 35 mix could also contribute to the ease of aeration. The difficulties in aeration of the mix made with the heated blend could be attributed to the increased viscosity of the ice cream mix itself and the inability of the reduced number of large aggregated protein particles to effectively stabilize the foam structure as it is formed, leading to structural collapse. However, the increased SEF in the hardened ice cream made with the heated blend suggests more partial coalescence and networking. This coupled with the high viscosity could be capable of stabilizing the foam structure once substantially aerated.

\subsection{Characteristics of hardened ice cream}

In our experiments, the ice cream manufacturing trials were performed two months apart. It was noted that there was some variation between trials (Tab. III).

\subsubsection{Solvent extractable fat}

The hardened ice cream contained increased levels of SEF compared to aged ice cream mixes (compare Tabs. II and III). The higher SEF is due to increased fat destabilization induced by the freezing and churning steps prior to hardening. Ice cream with WPC 35 as the sole source of MSNF had lower SEF than that made with LHSMP (Tab. III). This result contrasts with that of Pelan et al. [21] who used 1:1 palm kernel oil and coconut oil and observed an increase in SEF with the use of WPC 35 compared to SMP and also to that by Goff et al. [9] where an increase in the whey protein casein ratio increased fat destabilization.

Lower SEF in hardened ice cream generally appears to be correlated to a higher cumulative percentage of particles at $2.2 \mu \mathrm{m}$ (Tab. III).

When the ice cream mix is homogenised, the proteins coat the fat globules. However during ageing, proteins are displaced from 

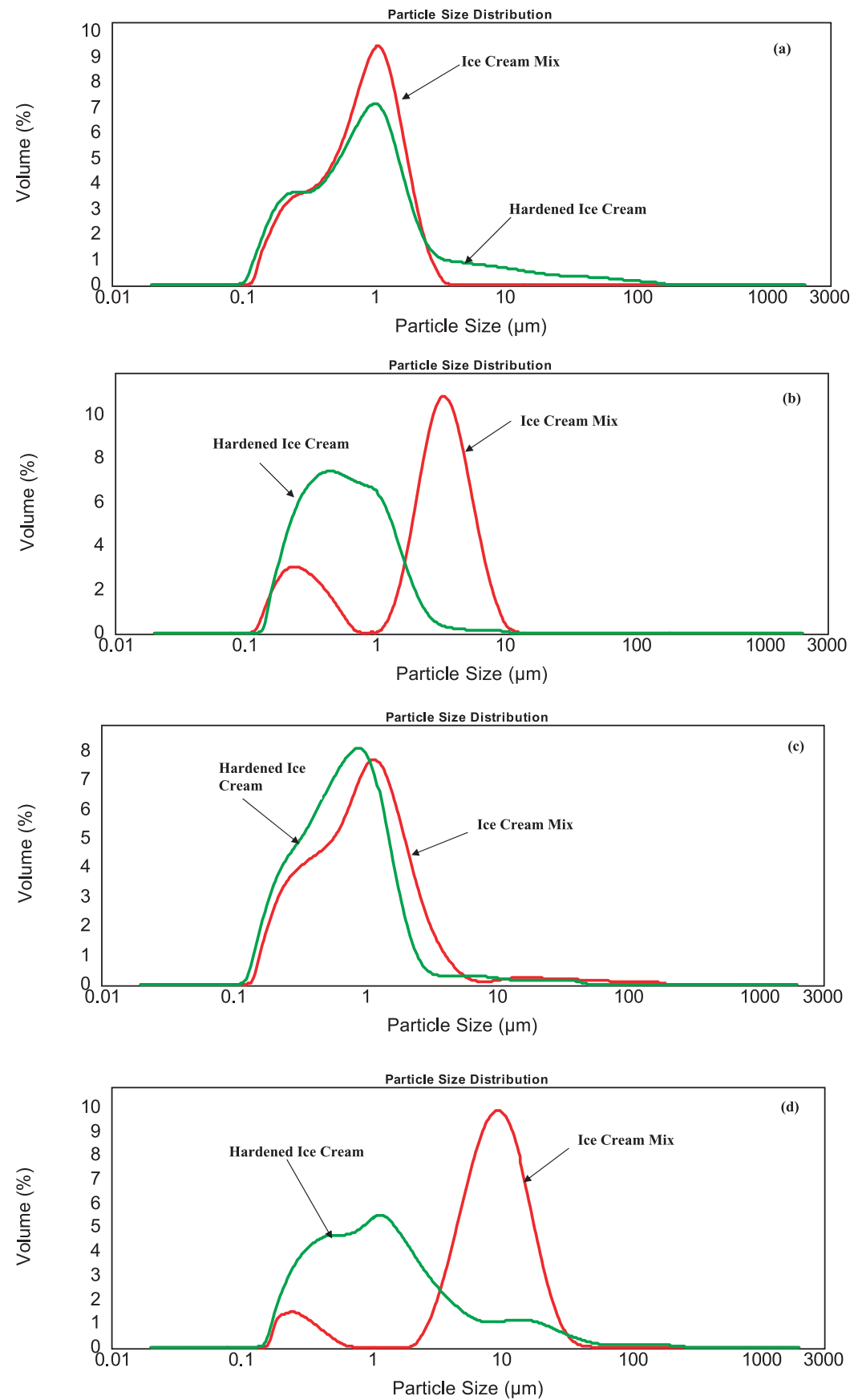

Figure 3. Effect of churning on the particle size distribution of ice cream mixes made with (a): LHSMP, (b) WPC 35, (c) Unheated blend and (d) Heated blend. (Results from trial 1 trial 2 trends were similar). 
the fat globule surface by the low molecular weight emulsifiers that are more surfaceactive than the proteins. Pelan et al. [21] observed increased fat destabilization (measured as extractable fat) when the concentration of the unsaturated monoglyceride was increased. However, the amount of extractable fat was very low and independent of the emulsifier concentration when saturated monoglycerides were used. The emulsifier used in our formulation was saturated monoglyceride and the low solvent extractable fat values observed in our study are in line with what might be expected. Moreover, Pelan et al. [21] suggested that in the presence of saturated monoglyceride, protein coverage might not be the only important factor controlling stability. A factor that needs to be considered includes the presence of monoglyceride crystals at the interface and therefore a better understanding of the functionality of emulsifiers in stabilizing fat droplets and air cells is required.

\subsubsection{Particle size distribution}

Shearing, aeration and freezing of the ice cream mix prior to hardening, results in partial coalescence of the ice cream mixes. This was observed as an increase in larger particle sizes in ice cream made with LHSMP (Fig. 3). However, with the use of WPC 35 and the heated blend (1:1 LHSMP and WPC 35) there was a shift in the PSD to a smaller size in the hardened ice cream (Fig. 3). This could be due to the fact that both WPC 35 and the heated blend (1:1 LHSMP and WPC 35) were not as effective as LHSMP for stabilising the ice cream mix emulsion and thus increased flocculation was observed in the ice cream mix. Thereby during the subsequent shearing, aeration and freezing process the flocs $(>1 \mu \mathrm{m})$ were disrupted.

\subsubsection{Melt resistance}

The melt resistance of ice creams made with a heated blend of LHSMP and WPC 35 was markedly better than those made with other sources of MSNF, which all had similar melt down rates (Fig. 4). The increased viscosity of the ice cream mix made with the heated blend of LHSMP and WPC 35 (Fig. 2) and the higher degree of fat destabilisation in the hardened ice cream (Tab. III) possibly contributed to the increased resistance of the final ice cream to melt compared to all the other ice creams.

\section{CONCLUSION}

The ice cream emulsion is a complex food system and there is a series of interdependent events that take place during the transformation of a quiescently stable emulsion to the final ice cream matrix. However, none of the ice cream mix properties measured in this study could be correlated directly to properties of the final ice cream.

The most striking relationship observed in this study was that between the particle cumulative $\%$ at $2.2 \mu \mathrm{m}$ in hardened ice cream and its melt resistance in the case of the ice cream made with a heated blend of LHSMP and WPC 35 (Compare Tab. III and Fig. 4). The most significant result of this study was that a change to the state of the aggregation of the proteins affected the melting properties of the ice cream. This is possibly due to the increased viscosity and the ability of the aggregates to network and prevent drainage from the ice cream matrix.

This study demonstrated that the melting properties of ice cream could be manipulated by the use of simple strategies such as type of MSNF and the degree of denaturation of whey proteins.

Acknowledgements: The aeration and freezing facilities at Nestle Ice Cream (Mulgrave, Victoria 3170 , Australia) were accessed for the production of experimental ice creams in this research. The support of Mr. Dan. Southee and Mr. Del Teesdale (Nestle Ice Cream, Australia) is gratefully acknowledged. Technical support for ice cream production at Nestle Ice Cream was provided by J. Ralph, J. Chebaro and D. Sekuloska. Financial support was provided by Dairy Research and Development Corporation of Australia. 




Figure 4. Effect of MSNF type on the melt resistance (room temperature) of ice creams made with - - - LHSMP, $-\triangle-$ WPC $35,-\boldsymbol{m}$ - Unheated blend and $-\square-$ Heated blend after $7 \mathrm{~d}$ of hardening. (Average of duplicate measurements from trial 1 with pooled SD, trial 2 trends were similar).

\section{REFERENCES}

[1] Berger K.G., Ice cream, in: Larsson K., Friberg S.E. (Eds.), Food Emulsions, Marcel Dekker Inc., New York, 1990, pp. 367-444.

[2] Campbell I.J., Pelan B.M.C., The influence of emulsion stability on the properties of ice cream, in: Buchheim W. (Ed.), Proceedings of the International Symposium on Ice Cream, Special issue 9803, Int. Dairy Fed., Brussels, Belgium, 1998, pp. 25-36.

[3] Dalgleish D.G., Denaturation and aggregation of serum proteins and caseins in heated milk, J. Agric. Food Chem. 38 (1990) 19951999.

[4] Dalgleish D.G., Bovine milk protein properties and the manufacturing quality of milk, Livestock Prod. Sci. 35 (1992) 75-93.

[5] Dickinson E., Parkinson E.L., Heat induced aggregation of milk protein stabilized emulsions: sensitivity to processing and composition, Int. Dairy J. 14 (2004) 635-645.

[6] Euston S.R., Hirst R.L., The emulsifying properties of commercial milk protein products in simple oil in water emulsions and in a model food system, J. Food Sci. 65 (2000) 934-940.

[7] Gelin J.L., Poyen L., Rizzotti R., Meste M.L., Courthaudon J.L., Lorient D., Interactions between food components in ice cream. Part 1: Unfrozen emulsions, Food Hydrocolloids 10 (1996) 385-393.

[8] Goff H.D., Colloidal aspects of ice cream. A review, Int. Dairy J. 7 (1997) 363-373.
[9] Goff H.D., Kinsella J.E., Jordan W.K., Influence of various milk protein isolates on ice cream emulsion stability, J. Dairy Sci. 72 (1989) 385-397.

[10] International Dairy Federation, Milk: determination of nitrogen content, FIL-IDF Standard 20B, 1993.

[11] International Dairy Federation, Milk and milk products : determination of nitrogen content. Routine method by combustion according to the Dumas principle, FIL-IDF Standard 185, 2000 (provisional).

[12] Keeney P.G., Frozen dairy products, in: Webb B.H., Johnson A.H., Alford J.A. (Eds.), Fundamentals of Dairy Chemistry, AVI Inc., Connecticut, USA, 1974, pp. 873913.

[13] Kokubo S., Sakurai K., Hakamata K., Tomita M., Yoshida S., The effect of manufacturing conditions on the de-emulsification of fat globules in ice cream, Milchwissenschaft 51 (1996) 262-265.

[14] Koxholt M., McIntosh T., Eisenmann B., Enhanced stability of ice-cream by using particulated whey proteins, Eur. Dairy Mag. 1 (1999) 14-15.

[15] Koxholt M.M.R., Eisenmann B., Hinrichs J., Effect of the fat globule sizes on the meltdown of ice cream, J. Dairy Sci. 84 (2001) 31-37.

[16] Lee F.Y., White C.H., Effect of ultrafiltration retentates and whey protein concentrates on ice cream quality during storage, J. Dairy Sci. 74 (1991) 1170-1180. 
[17] Loewenstein M., Haddad G.S., High temperature short time and ultra high temperature pasteurization of ice cream, Amer. Dairy Rev. 34 (1972) 82, 84, 90, 92, 117, 119.

[18] Loewenstein M., Haddad G.S., HTST and UHT pasteurization of ice cream. Part II : The influence of varying heat treatments on the effectiveness of some stabilizing agents, Amer. Dairy Rev. 34 (1972) 42-46, 52-53.

[19] Marshall R.T., Arbuckle W.S., Ice Cream, 5 th edn., Chapman \& Hall, New York, USA, 1996.

[20] McCrae C. H., Lepoetre A., Characterization of dairy emulsions by forward lobe laser light scattering-application to milk and cream, Int. Dairy J. 6 (1996) 247-256.

[21] Pelan B.M.C., Watts K.M., Campbell I.J., Lips A., The stability of aerated milk protein emulsions in the presence of small molecule surfactants, J. Dairy Sci. 80 (1997) 26312638.

[22] Regand A., Goff H.D., Effect of biopolymers on structure and ice recrystallization in dynamically frozen ice cream model systems, J. Dairy Sci. 85 (2002) 2722-2732.

[23] Sakurai K., Kokubo S., Hakamata K., Tomita M., Yoshida S., Effect of production condi- tions on ice cream melting resistance and hardness, Milchwissenschaft 51 (1996) 451454.

[24] Standards Association of Australia, Methods of chemical and physical testing for the dairying industry. General methods and principles - Determination of fat - gravimetric method (SAA AS 2300.1.3), 1988.

[25] The Association of Official Analytical Chemists, Protein nitrogen content of milk Kjeldahl method (AOAC Official method 991.22), 2000.

[26] The Association of Official Analytical Chemists, Casein nitrogen content of milk Kjeldahl method (AOAC Official method 998.06), 2000

[27] Tolstoguzov V., Thermodynamic aspects of biopolymer functionality in biological systems, foods, and beverages, Crit. Rev. Biotechnol. 22 (2002) 89-174.

[28] Udabage P., Augustin M.A., Dairy ingredients for ice cream, Aust. J. Dairy Sci. Technol. 58 (2003) 21-25.

[29] Walstra P., Oortwijn H., The membranes of recombined fat globules. 3. Mode of formation, Neth. Milk Dairy J. 36 (1982) 103-113. 